https://www.amerabra.org; https://fspu.uitm.edu.my/cebs; https://www.emasemasresources.com/ $9^{\text {th }}$ Asian Conference on Environment-Behaviour Studies Perdana Kota Bharu, Kelantan, Malaysia, 28-29 Jul 2021

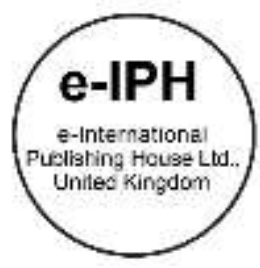

\title{
COVID-19 Pandemic: Youth Compliance Behaviors towards Movement Control Order (MCO)
}

\author{
Izzah Nur Aida Zur Raffar ${ }^{1}$, Zuriani Ibhrim ${ }^{2}$, Wan Kamal Mujani ${ }^{3}$, Najmi Hayati 4 \\ ${ }^{1}$ Academy of Islamic Contemporary, Universiti Teknologi MARA (UiTM), \\ ${ }^{2}$ Faculty of Education, Humanities and Arts, Kolej Universiti Poly-Tech MARA, \\ ${ }^{3}$ Faculty of Islamic Studies, Universiti Kebangsaan Malaysia, \\ ${ }^{4}$ Fakultas Agama Islam, Universitas Islam Riau, Indonesia \\ izzahnur@uitm.edu.my, zuriani@gapps.kptm.edu.my, inawan@ukm.edu.my, annajmi.edu@gmail.com \\ Tel: 018-3636191
}

\begin{abstract}
This analysis aims to investigate Muslim youths' compliance behavior towards the Malaysian government's MCO and analyze the differences in compliance behaviors towards MCO between male and female youth. The design of this study is a survey study on 545 respondents who were purposefully selected among Muslim youth. Meanwhile, the data was analyzed using descriptive statistical techniques and inferential test Mann-Whitney U. The results of the study revealed that the majority of youths reacted positively and complied towards MCO. While the Mann-Whitney U test showed no significant difference between the compliance behaviors of male and female youth towards $M C O(p>0.05)$.
\end{abstract}

Keywords: COVID-19 pandemic, behavior, youth, Movement Control Order (MCO).

eISSN: 2398-4287C 2021. The Authors. Published for AMER ABRA cE-Bs by e-International Publishing House, Ltd., UK. This is an open access article under the CC BYNCND license (http://creativecommons.org/licenses/by-nc-nd/4.0/). Peer-review under responsibility of AMER (Association of Malaysian Environment-Behaviour Researchers), ABRA (Association of Behavioural Researchers on Asians/Africans/Arabians) and cE-Bs (Centre for Environment-Behaviour Studies), Faculty of Architecture, Planning \& Surveying, Universiti Teknologi MARA, Malaysia.

DOI: https://doi.org/10.21834/ebpj.v6i17.2850

\subsection{Introduction}

At present, the World Health Organization (WHO) (2020) defines COVID-19 as Coronavirus (CoV) to be a dangerous virus that could cause respiratory tract infections. According to Mohd Nur Hidayat et al. (2020) and Muhammad Adnan et al. (2020), coronavirus disease (COVID-19) is an infectious disease known as severe acute respiratory syndrome coronavirus (SARS) and Middle Eastern respiratory syndrome (MER-CoV). This virus was identified in Wuhan, China late 2019, and this pandemic has continuously spread throughout the world. The protracted duration of the COVID-19 pandemic has changed the daily life scenario of the members of society. The COVID-19 social restrictions imposed by various nations including Malaysia have impacted the politics, socio-economy, well-being, and educational systems of the country (Abdul Rashid, 2020).

Numerous initiatives and plans by the authorities to contain and eradicate the virus and ensuring the continuance of the people's activities and livelihood (Mohd Nur Hidayat et al., 2020). The government has strategies for the public for self-isolated and encourage people to stay healthy by using masks and sanitizers for infectious viruses and help protect older people and those with underlying health problems from getting infected. Preventive measures such as the execution of a movement control command (MCO) or Movement Control Order have led to changes in the daily lifestyle of the society compared to the previous lifestyle (Abd Aziz et al., 2021), which is not only applicable in Malaysia but also in Indonesia.

eISSN: 2398-42870 2021. The Authors. Published for AMER ABRA cE-Bs by e-International Publishing House, Ltd., UK. This is an open access article under the CC BYNCND license (http://creativecommons.org/licenses/by-nc-nd/4.0/). Peer-review under responsibility of AMER (Association of Malaysian Environment-Behaviour Researchers), ABRA (Association of Behavioural Researchers on Asians/Africans/Arabians) and CE-Bs (Centre for Environment-Behaviour Studies), Faculty of Architecture, Planning \& Surveying, Universiti Teknologi MARA, Malaysia.

DOI: https://doi.org/10.21834/ebpj.v6i17.2850 
The Indonesian authorities have implemented movement orders to prevent the rapid spread of Corona Virus Disease (COVID-19). These include school closures, restricting public gatherings and religious activities, and imposing a "stay at home" policy (A. Miyanza et al., 2020).

This restriction movement order or MCO is one of the measures recommended to be executed in a country to cope with pandemics. The order is evident as the number of cases is increasing every day. Without proper understanding and control, the virus could contribute to the risk of more deaths in the country (Halim, 2020). During the movement control order (MCO), several issues must be looked into and carefully considered. One of the most important focuses of the administration is enforcing Standard Operation Procedure (SOP) in all conditions and situations to maintain public safety, health, and welfare. As part of the MCO act, the Malaysian administration has imposed roadblocks and cross districts and states restrictions (Safeek Razali, 2021). Citizens must also maintain cleanliness, good health and comply with social distancing and limit their social movement within a radius of 10 kilometers (Mohd Nur Hidayat et al., 2020). According to the Director of the Bukit Aman Crime Prevention and Community Safety Department, any party who violates the SOP of the MCO will be compound RM1,000 starting July 2020 (Nor Farhani Che Ad, 2020).

Despite the measures and efforts made, there are still some cases reported in Malaysia where public individuals, dignitaries, politicians, celebrities, civil servants, and companies do not comply with the SOP set by the authorities (Juani Munir, 2021). Meanwhile, the youth are no exception in not following the SOP. Kelantan state police chief Datuk Shafien Mamat from his records stated he found that teens or young adolescence represent the highest number of age groups that violate the SOP set to control and contain the spread of the Covid19 virus (Rohana, 2021). Thus, these youth issues need attention because they play a big part in helping the authorities to control, contain and break the COVID-19 chain. Statistics from the Department of Statistics Malaysia (2019) show that the population aged between 15 to 30 years is estimated at 9.2 million.

Therefore, how do youth compliance behaviors towards Movement Control Order (MCO)? and are there differences in youth compliance behaviors towards MCO between genders? To understand the situation better, a study was conducted to investigate the Muslim youths' compliance behavior towards the Standard Operating Procedures (SOP) during the Movement Control Order (MCO). In addition, the study will also analyze the differences in compliance behaviors towards Movement Control Order (MCO) between male and female youth. Hypotheses were formed to answer the questions and objectives of the study, namely null hypothesis: There is no significant difference between the compliance behavior of male and female youth towards Movement Control Order (MCO).

\subsection{Literature Review}

A pandemic is dangerous and is spreading rapidly on a massive scale across the world involving large populations. Usually, the disease that causes a pandemic is a new (novel) disease in which the human population has no immunity or resistance against the disease. Pandemics are not new and have occurred at different stages in human history (Ferguson et al., 2020). This is due to the increased incidence of viral diseases in animals (Madhav et al., 2017). Given the increasing frequency of pandemics, many researchers include Garrett (2007) and most recently Madhav et al. (2017) and Fan et al. (2018) argue that large-scale global epidemics are inevitable. Ferguson et al. (2020) from Imperial College London is part of the COVID-19 Response Team claimed that COVID-19 was the most severe episode as such an event like this ever occurred in 1918 leading to the Spanish flu epidemic. Barro (2020) concluded that during the Spanish Influenza pandemic of 1918, many deaths were inevitable. The number of COVID-19 cases is still low compared to the Spanish flu in 1918. Pandemics had a severe negative impact on economic activity over a long period. Nazir \& Rashid's "Community callousness towards lockdown of COVID-19 pandemic and the role of preventive specialist" focuses on a study on society members who approach health facilities in Srinagar, India. Observations on individuals who break the rules of social distancing practice responded that "when I am healthy, COVID-19 will not infect me". Regression analysis found that there was a statistically significant difference between "because I am healthy, COVID-19 will not infect me", "COVID-19 is a scam by the media", "God will help us", "tired of staying indoors" and " go out and buy groceries ". Evidence suggested that young people (29-32 years) are exposed to several social situations based on their personal choices, environmental factors, and a change of lifestyle. This age group is prone to taking life and duties for granted. They are inherently rebellious and anti-social, as well as breaking the rules with not much difficulty (Nazir \& Rashid, 2020).

Based on the previous studies, the study on the COVID-19 pandemic is gaining attention and development nowadays. The Movement Control Order (MCO) approach is the best and most appropriate method today by the government to curb the pandemic to protect the lives and safety of the people. However, studies on the relationship between the level of compliance with SOPs of Malaysians, especially among youths are not widely discussed. Thus, this study attempts to investigate the behavior of youth compliance in Malaysia towards the Standard Operating Procedures (SOP) through the MCO to curb the spread of COVID-19. The study will also analyze the differences in youth compliance behaviors towards Movement Control Order (MCO) between genders.

\subsection{Methodology}

This study is a quantitative study using a survey study design through a questionnaire distributed to respondents. This method is applied to obtain data quantitatively based on the objectives of the study. The survey study design is used widely to explain various issues like attitudes, views, feelings, and behaviors of respondents (Chua, 2006). Rozmi (2016) claimed that survey research is a social survey that can examine and study many aspects of the social world and human behavior such as behavior, values, attitudes, beliefs, perceptions in addition to expectations and predictions of understanding, phenomena, levels of knowledge, favorites, etc. 
The sample of respondents in this study consisted of 545 respondents and is purposefully selected. The characteristics of the respondents are Muslim teenagers, aged 15 to 30 years old, and Malaysian citizens only.

The selection of samples made based on non-probability sampling which uses the purposive sampling method on respondents who have certain characteristics and criteria based on the study sample. Sampling is an important aspect of quantitative research methods because the information obtained after the analysis is made based on the selected sample (Creswell, 2009).

A questionnaire consisting of four sections is applied to collect the entire study data. However, this research paper will describe only one part involving 11 questions covering social aspects. To evaluate the validity of the content of the items of this questionnaire, the validity of the items was evaluated by Dr. Norshariani Abd. Rahman from a lecturer at The Islamic Hadhari Institute, The National University of Malaysia as an expert evaluator on the suitability of the questionnaire items provided. Meanwhile, a pilot study was conducted to evaluate the reliability and consistency of the study questionnaire through the value of Cronbach's Alpha index coefficient that can be adopted in the actual study. Typically, the number of pilot study samples does not require a large sample size. According to the views of Creswell (2009) suggest the minimum number of samples selected is as many as 30 to people only.

Thus, this pilot study conducted a total of 70 respondents from Kolej Universiti Poly-Tech MARA (KUPTM) and Universiti Teknologi MARA (UiTM) consisting of 20 male students and 50 female students. The reliability of the Muslim youth adherence questionnaire instrument to the movement control order through the value of Cronbach's Alpha reliability coefficient obtained a reliability value of 0.820 . Thus, the reliability value of this research instrument indicates a good level of interpretation and is acceptable for use in actual studies (Sekaran, 2010). The instrument is in a position of high reliability, effectiveness, and consistency.

Meanwhile, the data was analyzed using descriptive statistical techniques and inferential test Mann-Whitney U using IBM SPSS (Statistical Package for the Social Sciences) Statistics. The descriptive analysis uses percentages, frequency distributions, and the means values are most suitable to be used so that researchers get more comprehensive and comprehensive information, detailed and accurate as required in the objectives of the study. According to Chua (2006), descriptive analysis is applied to express and describe a variable in a phenomenon logically using particular methods. Aidit \& Ahmad Syahir (2014) stated where the focus of descriptive research is to explain the scenarios and problematic issues on the behavior of a group of people. Meanwhile, in testing the null hypothesis which states that there is no real difference between the two groups of data independent samples, Mann-Whitney testing can be performed. This test is also called the $U$ test because it is to tests the null hypothesis (Teguh Sriwidadi, 2011).

\subsection{Findings}

This analysis aims to investigate Muslim youths' compliance behavior towards the Malaysian government's MCO. As shown in Table 1, analysis of the findings of the study on the compliance behavior of Muslim youths to SOP through MCO recorded the highest mean value on the item "I always scan the MY SEJAHTERA QR CODE before entering a premises" (mean = 3.89), followed by the item "I always scan my body temperature before entering a premises" (mean $=3.86$ ), "I avoid being in crowded and narrow areas during MCO" (mean-3.84), "I always follow the instructions of the National Security Council not to cross the district or state during MCO "(mean = 3.81),"I sit at home if there is no need to go out "(mean = 3.79)," I always follow SOP instructions when eating at restaurants during MCO season "(mean = 3.79)," I always practice social imprisonment when outside "(mean = 3.78$), "$ I avoid chatting at close range as recommended by the Ministry of Health $(\mathrm{MOH})$ "(mean = 3.67)," I do not shake hands and touch when meeting with blacks relatives or close friends "(mean = 3.43$)$ and the item" I did not visit relatives or friends during MCO "(mean = 3.38). Meanwhile, the item "I do not allow guests to visit my house during $\mathrm{MCO} "$ recorded the lowest mean score $($ mean $=3.28)$.

Table 1. Compliance Behavior of Muslim Youths to Standard Operating Procedures (SOP) Through Movement Control Orders (MCO)

\begin{tabular}{|c|c|c|c|c|c|c|}
\hline \multirow{2}{*}{ No } & \multirow[b]{2}{*}{ Statement } & \multicolumn{4}{|c|}{ Percent (\%) \& Frequency $(\mathrm{N})$} & \multirow[b]{2}{*}{ Mean } \\
\hline & & $\begin{array}{l}\text { Strongly } \\
\text { disagree }\end{array}$ & $\begin{array}{l}\text { Do not } \\
\text { agree }\end{array}$ & Agree & Strongly Agree & \\
\hline 1 & I always practiced social incarceration while outside. & $\begin{array}{l}0.2 \% \\
(1)\end{array}$ & $\begin{array}{c}0.4 \% \\
(2)\end{array}$ & $\begin{array}{l}21.1 \% \\
(115)\end{array}$ & $\begin{array}{l}78.3 \% \\
(427)\end{array}$ & 3.78 \\
\hline 2 & $\begin{array}{l}\text { I do not shake hands and touch when meeting relatives or } \\
\text { close friends. }\end{array}$ & $\begin{array}{l}1.5 \% \\
(8)\end{array}$ & $\begin{array}{l}11.2 \% \\
(61)\end{array}$ & $\begin{array}{l}30.5 \% \\
(166)\end{array}$ & $\begin{array}{l}56.9 \% \\
(310)\end{array}$ & 3.43 \\
\hline 3 & I do not allow guests to visit my house during MCO. & $\begin{array}{l}1.3 \% \\
(7)\end{array}$ & $\begin{array}{c}15.2 \% \\
(83)\end{array}$ & $\begin{array}{l}38.2 \% \\
(208)\end{array}$ & $\begin{array}{c}45.3 \% \\
(247)\end{array}$ & 3.28 \\
\hline 4 & $\begin{array}{l}\text { I did not visit the homes of relatives or friends during the } \\
\text { MCO. }\end{array}$ & $\begin{array}{l}1.7 \% \\
(9)\end{array}$ & $\begin{array}{c}13.4 \% \\
(73)\end{array}$ & $\begin{array}{l}30.3 \% \\
(165)\end{array}$ & $\begin{array}{c}54.7 \% \\
(298)\end{array}$ & 3.38 \\
\hline 5 & $\begin{array}{l}\text { I always scan MY SEJAHTERA QR CODE before entering a } \\
\text { premise. }\end{array}$ & $0 \%$ & $\begin{array}{l}0.6 \% \\
(3)\end{array}$ & $\begin{array}{c}9.7 \% \\
(53)\end{array}$ & $\begin{array}{l}89.7 \% \\
(489)\end{array}$ & 3.89 \\
\hline 6 & $\begin{array}{l}\text { I always scan my body temperature before entering a } \\
\text { premise. }\end{array}$ & $\begin{array}{l}0 \% \\
(0)\end{array}$ & $\begin{array}{l}0.4 \% \\
(2)\end{array}$ & $\begin{array}{c}13.4 \% \\
(73)\end{array}$ & $\begin{array}{l}86.2 \% \\
(470)\end{array}$ & 3.86 \\
\hline 7 & I sit at home when there is no need to go out. & $\begin{array}{l}0.4 \% \\
(2)\end{array}$ & $\begin{array}{l}1.3 \% \\
(7)\end{array}$ & $\begin{array}{c}17.1 \% \\
(93)\end{array}$ & $\begin{array}{c}81.3 \% \\
(443)\end{array}$ & 3.79 \\
\hline 8 & $\begin{array}{l}\text { I have always complied with the National Security Council's } \\
\text { directive not to cross county or state during the MCO. }\end{array}$ & $\begin{array}{c}0.4 \% \\
(2)\end{array}$ & $\begin{array}{c}1.1 \% \\
(6)\end{array}$ & $\begin{array}{c}15.2 \% \\
(83)\end{array}$ & $\begin{array}{l}83.3 \% \\
(454)\end{array}$ & 3.81 \\
\hline 9 & $\begin{array}{l}\text { I always follow the SOP instructions when eating at } \\
\text { restaurants during the MCO season. }\end{array}$ & $\begin{array}{l}0.6 \% \\
(3)\end{array}$ & $\begin{array}{l}0.7 \% \\
(4)\end{array}$ & $\begin{array}{l}17.6 \% \\
(96)\end{array}$ & $\begin{array}{c}81.1 \% \\
(442)\end{array}$ & 3.79 \\
\hline 10 & I avoid being in crowded and cramped areas during MCO. & $\begin{array}{l}0.2 \% \\
(1)\end{array}$ & $\begin{array}{c}1.1 \% \\
(6)\end{array}$ & $\begin{array}{l}13.2 \% \\
(72)\end{array}$ & $\begin{array}{l}85.5 \% \\
(466)\end{array}$ & 3.84 \\
\hline
\end{tabular}


11 I avoid chatting at close range as recommended by the Ministry of Health $(\mathrm{MOH})$
$2.8 \%$

(15)
$24.4 \%$ (133)
$71.9 \%$ (392)

(Source:) Questionnaire 2021

The study also will analyze the differences in compliance behaviors towards MCO between male and female youth. Based on Table 2 , the results of the inferential analysis test using the Mann-Whitney $U$ test have accepted the null hypothesis of this study because there is no significant difference between the compliance behaviors of male and female youth towards $M C O(p>0.05, p=0.446)$.

Table 2. Mann-Whitney U Youth Compliance Behaviors Towards MCO Across Gender

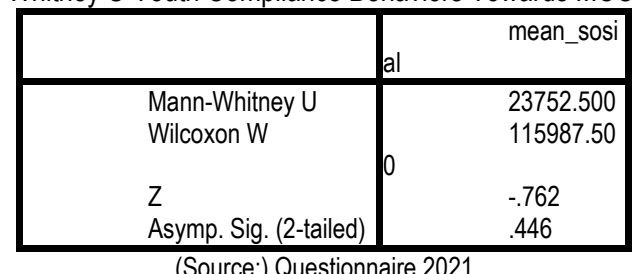

\subsection{Discussion}

The results of the study found that the majority of respondents among youths reacted positively and complied with SOP through MCO by constantly scanning the MY SEJAHTERA QR CODE before entering a premises (mean $=3.89$ ) reached $(99.4 \%, n=542)$. This finding is as explained by the Ministry of Housing and Local Government (2020) that Malaysians need to register by scanning the QR Code through the MySejahtera application or record the name, phone number, date and time of arrival at the premises and temperature readings into the record book for contact tracing. Thus, the majority of respondents scan the MySejahtera app probably because they are comprised of youths known to frequently use mobile phones and easily do things based on smartphone technology.

The analysis of the study also found that respondents among youths followed the instructions of the authorities during the period of MCO by sitting at home if there was no need to go out (mean $=3.79)$ reached $98.4(n=536)$. These findings by Zuriani et al. (2021) claimed that movement control orders must be complied with by all Malaysians to confine themselves in residences and not to conduct large-scale gatherings involving many people in venues whether for worship or otherwise. As the movement control order gazetted is from the Ulul-Amri government to the people where it is in line with the government's jurisdiction which needs to guarantee the welfare of its people. Thus, the obedience of the people in this country towards the MCO is obligatory based on the words of Allah in the Qur'an (4:59) which means: ' $O$ you who have believed, obey Allah and obey the Messenger and those in authority among you.

In addition, the results of the study found that youth respondents always practice social imprisonment while outside (mean $=3.78$ ) reached $99.4 \%(n=542)$ as a measure to comply with SOP during MCO. These findings are supported by Mohd Nur Hidayat et al. (2020) who stated that society should practice social incarceration. The Malaysian government has also taken drastic measures in the face of the COVID19 pandemic, especially the ban on creating any large-scale public gatherings and being the focus of the public.

The findings also showed that youth respondents did not shake hands and touch when meeting with relatives or close friends (mean $=3.43$ ) reached $(87.4 \%, n=476)$. Shaking hands may cause the spread of the COVID-19 virus. The culture of shaking hands is still firmly ingrained in society. Therefore, for now, youth and members of society should understand and there should be no feeling of resentment if the act of shaking hands is not practiced anymore as it is the best way to prevent COVID-19 from spreading.

Although the item "I do not allow guests to visit my house during MCO" recorded the lowest mean value (mean = 3.28 ), but the percentage and frequency for this item recorded the highest value of $16.5 \%(n=90)$ compared to other items. This shows that a total of 90 respondents among the youth allowed guests to come and visit their homes during MCO. Meanwhile, the item "I did not visit the house of a relative or friend during MCO" also recorded a low mean value (mean $=3.38$ ), but the percentage and frequency of this item were high at $15.1 \%(n=82)$. This shows 82 youth who visited relatives and friends during the MCO. This is contrary to the SOP of the festive celebration issued by the authorities, where no visiting activities are allowed even to visit family members and relatives (Shuhaniza, 2021). As a result, the increase in COVID-19 clusters contributed to the Aidilfitri celebrations (Fahmy, 2021). Therefore, this matter needs to be given attention, especially towards the youth as that they can practice proper SOP during the MCO to curb the spread of the COVID-19 virus in Malaysia.

\subsection{Conclusion \& Recommendations}

Various efforts were made by the authorities to ensure that the spread of the COVID-19 pandemic is contained and curbed, especially with the implementation of SOPs during the MCO period. This study is carried out to investigate the compliance behavior of Muslim youths to the Standard Operating Procedures (SOP) through the Movement Control Order (MCO) and researchers found out that the compliance behavior patterns of youth are at a good and satisfactory level. The study also analyzes the differences in youth compliance behaviors towards MCO across gender and researchers found out that there is no significant difference between the compliance behaviors of male and female youth towards MCO. 
Based on statistics results, respondents are reacted positively and complied towards MCO as always scanning MY SEJAHTERA QR CODE before entering a premises, scan body temperature before entering premises, avoids being in crowded and narrow areas, always obey the National Security Council instructions to avoid crossing districts or states, sit at home if there is no need to go out, always obey SOP instructions when eating at restaurants, always practice social imprisonment when outside, avoid chatting at close range as recommended by the Ministry of Health $(\mathrm{MOH})$, do not shake hands and touch when meeting relatives or close friends, do not visit the home of a relative or friend and does not allow guests to visit the home during the MCO.

This study highlights how compliance youth attitudes towards MCO and the importance of youth to know and practice MCO in new norms to curb the COVID-19 pandemic. This is because youth is an asset to the country. Hence, they need to pay attention to good personalities, listen to instructions and behave nobly to be icons and models for the country. Therefore, members of society should join forces to curb the spread of the COVID-19. Cooperation and awareness from the members of society by complying with the SOPs during the MCO period are expected to help restore the country's well-being in terms of security, health, and well-being. This study also provides suggestions in helping stakeholders in youth institutions to formulate youth development plans more progressively. It is also suggested that future research focus on aspects of strategic methods in ensuring compliance with SOPs and looking at correlations between variables.

\section{Acknowledgment}

This research was funded by Universiti Teknologi MARA under the Teja Internal Grant (GDT 2021/1-8) and University Research Grant (URG) Kolej Universiti Poly-Tech MARA Kuala Lumpur (KUPTM 2020 -2021).

\section{Paper Contribution to Related Field of Study}

This paper contributes to the public's knowledge of youth behavior in complying with current laws gazetted by the authorities, as well as helping stakeholders in youth institutions to formulate youth development plans more progressively.

\section{References}

A. Miyanza Rezkyawan, L. T., Gabriela, J., Havian Daulung, T. (2020). Menjaga Kondisi Psikis Selama PSBB Dalam Masa Pandemi Covid-19 Di Indonesia. Jakarta: Fakultas Kedokteran Universitas Katolik Indonesia.

Abd Aziz, N. N., Mohd Abdul Kadir, J., Mohamad Hassan, N. N. N. ., Zakaria, N. B. ., \& Premananto, G. C. (2021). The Role of Media on Knowledge, Awareness and Students' Attitude during Movement Control Order (MCO). Environment-Behaviour Proceedings Journal, 6 (16), 23-29.

Abdul Rashid, A. A., Nurhafizah, M. S., Nor Hamizah, A. R. 2020. Wabak Covid-19: Pengurusan Aspek Kesihatan Mental Semasa Norma Baharu. International Journal of Social Science Research, 2 (4), 156-174.

Aidit, G. \& Ahmad Syahir, S. (2014). Manual Penyelidikan Secara Islam. Shah Alam: Penerbit Institut Perkembangan Minda (INMIND).

Amree, A. (2021, June 5). Adu kepada MyGCC Jika Ada Kes Langgar SOP. Utusan. https://www.utusan.com.my/berita/2021/06/

Barro, R. J. (2020). Non-Pharmaceutical Interventions and Mortality in U.S. Cities during the Great Influenza Pandemic, National Bureau of Economic Research. pp. 19181919

Chua, Y. P. (2006). Kaedah Penyelidikan. Kuala Lumpur: McGraw-Hill Sdn. Bhd.

Creswell, J. W. (2009). Research Design Qualitative, Quantitative and Mixed Methods Approaches. Lincoln: University of Nebraska.

Department of Statistics Malaysia. (2019). Buku Tahunan Perangkaan. Malaysia: Percetakan Nasional.

Fahmy, A. R. (2021, May 26). COVID-19: 12 kluster Berkaitan Sambutan Aidilfitri Dikesan. Berita Harian. https://www.bharian.com.my/berita/nasional/2021/05/820987

Fan, V. Y., Jamison, D. T., \& Summers, L. H. (2018). Pandemic Risk: How Large Are The Expected Losses? Bulletin Of The World Health Organization, 96 (2), $129-134$.

Ferguson, N., Laydon, D., Nedjati Gilani, G., Imai, N., Ainslie, K., Baguelin, M., Bhatia, S., Boonyasiri, A., Cucunuba Perez, Z., Cuomo-Dannenburg, G., Dighe, A., Dorigatti, I., Fu, H., Gaythorpe, K., Green, W., Hamlet, A., Hinsley, W., Okell, L., Van Elsland, S., Ghani, A. (2020). Impact of Non-Pharmaceutical Interventions (Npis) To Reduce COVID-19 Mortality And Healthcare Demand. London: Imperial College.

Garrett, T. A. (2007). Economic Effects of the 1918 Influenza Pandemic. US: Federal Reserve Bank of St. Louis, 26.

Halim, A. A. (2020). Cabaran COVID-19 menurut perspektif Akidah dan Hadis. Institut Kajian Hadis Dan Akidah, 7(2), 1-16.

Juani Munir, A. B. (2021, June 13). Ahli Politik, Selebriti Langgar Sop Mengecewakan. Utusan Malaysia. https://www.utusan.com.my/terkini/2021/06/.

Madhav, N., Oppenheim, B., Gallivan, M., Mulembakani, P., Rubin, E., \& Wolfe, N. (2017). Pandemics: Risks, Impacts, and Mitigation. In D. T. Jamison, H. Gelband, S. Horton, P. Jha, R. Laxminarayan, C. N. Mock, \& R. Nugent (Eds.), Disease Control Priorities: Improving Health and Reducing Poverty (3rd ed.). 
Malaysia: an Overview From Islamic Perspective. Al-Maqasid: International Journal of Maqasid Studies \& Advanced Islamic Research, 1 (2), 1-17.

Muhammad Adnan, S., Suliman, K., Abeer, K. Nadia, B., Rabeea, S. (2020). COVID-19 Infection: Origin, Transmission, And Characteristics Of Human Corona Viruses. Journal of Advanced Research, 24 (1), 91-98.

Nazir S, Rashid A. (2020). Community Callousness Towards Lockdown Of COVID-19 Pandemic And The Role Of Preventive Specialist. International Journal of Research and Review. 7 (4), 232-236.

Nor Farhani, C. A. (2020, July 21). Polis Mula Kompaun RM1,000 Langgar SOP. Berita Harian. https://www.bharian.com.my/berita/nasional/2020/07/713638.

Rohana, M. N. (2021, January 18). Belia Paling Ramai Langgar SOP. Utusan. https://www.utusan.com.my/berita/2021/01/

Rozmi, I. (2016). Metodologi Penyelidikan Teori dan Praktis. Bangi: Penerbit Universiti Kebangsaan Malaysia.

Safeek Affendy, R. (2021, February 16). Larangan Rentas Daerah, Negeri Kekal Elak Penularan COVID-19. Berita Harian. https://www.bharian.com.my/berita/nasional.

Sekaran, U. (2010). Research Methods for Business: A Skill Building Approach. Singapore: John Wiley \& Sons.

Shuhaniza, S. (2021, May 10). PM Umum PKP Seluruh Negara, Ziarah Aidilfitri Tak Dibenarkan. Mstar Online. https://www.mstar.com.my/lokal/semasa/2021/05/10/

Zuriani, I., Wan Kamal, M., Izzah Nur Aida, Z. R., Suhaila, A. A., Zaleha, M. (2021). Perintah Kawalan Pergerakan Menurut Perspektif Islam Dalam Membendung Wabak Covid-19. The 12th International Malaysian Studies Conference (MSC12), 17-18 August 2021. 